autoimmune myopathy and inclusion body myositis. Mean follow up was 82 months. Frequencies of disphagia, respiratuary muscle involvement and intertstitial lung disease were $29 ; 5 ; 34 \%$ respectively. Twenty-one percent of the patients had associated malignancy. The mean daily prednisolone dosage and total amount was $7.5 \mathrm{mg} /$ day and $9000 \mathrm{mgs}$. Mortality was 13\%. Initial mean MDI at the time of diagnosis was $1.6 \pm 3.0$ (range, $0-14$ ) and the last DMI score recorded was $6.1 \pm 4.7$ (range, $0-21$ ). After the last assessment the proportion of patients without damage was $8 \%$ and whose score was 4 were $37 \%$. The last DMI score was significantly higher than the first DMI score $(p<0.001)$. The last DMI in females and patients with calcinosis were significantly high $(p=0.002 ; p=0.007)$. The last $\mathrm{DMI}$ score and disease duration were weakly corelated $(r=0.35 \mathrm{p}=0.001)$. A moderately significant correlation was found between the last DMI score, the duration of glucocorticoid use and the total dose used ( $r=0.48 p<0.001 ; r=0.45 p<0.001)$. Conclusions: Our long term follow up data showed that persistent organ damage assessed by DMI and mortality were high in patients with IIM and over half of patients developed severe damage. Organ damage was detected in some patients at presentation and DMI scores were significantly increased during the follow up. DMI scores were found high in females and in patients with calcinosis. There were significant correlation between disease duration, the duration of glucocorticoid use, the total dose used and DMI scores. Current treatments and strategies have been insufficient at improving the prognosis of patients with IIM and new treatment strategies and drugs are needed.

Disclosure of Interest: None declared

DOI: 10.1136/annrheumdis-2018-eular.4872

\section{SAT0490 INCIDENCE AND PREVALENCE OF SYSTEMIC SCLEROSISIN AN ITALIAN ALPINE VALLEY DURING A 18-YEAR LONG PERIOD}

F. Dall'ara ${ }^{1}$, A. Premoli ${ }^{1}$, S. Zingarelli ${ }^{2}$, M.G. Lazzaroni ${ }^{1}$, A. Tincani ${ }^{1}$, M.G. Fenini ${ }^{3}$, F. Inverardi ${ }^{4}$, R. Furloni ${ }^{4}$, M. Scarsi ${ }^{4}$, P. Airò ${ }^{2} .{ }^{1}$ Rheumatology and Clinical Immunology, Department of Clinical and Experimental Sciences, Spedali Civili and University of Brescia; ${ }^{2}$ Rheumatology and Clinical Immunology, Spedali Civili of Brescia, Brescia; ${ }^{3}$ Clinical Pathology Laboratory, ${ }^{4}$ Rheumatology, Internal Medicine Department, ASST Valcamonica, Ospedale di Esine, Esine, Italy

Background: Not much information is available on the variations in the incidence and prevalence of Systemic Sclerosis (SSc) over time.

Objectives: To investigate the epidemiology of SSc in Valcamonica, an Alpine valley in northern Italy (Brescia Province, Lombardy region), during a 18-yearlong period.

Methods: All patients with diagnosis of SSc living in Valcamonica between 1999 and 2016 were identified by capture/recapture method using: 1) clinical databases of the only secondary Rheumatology Unit present in the valley (Esine Hospital), and of the only tertiary referral centre for this area (Spedali Civili, Brescia); 2) administrative data (ASST Valcamonica, Esine), extracting all records with the ICD-10 code for SSc (710.1). Clinical charts were reviewed and patients included in the analysis when either the 1980 ARA or the 2013 ACR/EULAR classification criteria for SSc were satisfied. Incidence was calculated using the number of new cases observed as the numerator, and the Valcamonica population as the denominator for each year; to study temporal changes, mean yearly incidence during 3 different 6 year intervals was calculated (table 1). Prevalence rates were estimated at 4 different time points dividing the number of living patients by the number of individuals in the population (table 2). Survival, incidence and prevalence rates were expressed with $95 \%$ confidence intervals. Incidence and prevalence rates observed in different periods were compared using ANOVA test. Demographic data were expressed as the medians (IQR).

Results: General population with age over 14 years living in Valcamonica varied during the evaluated period between 85168 (1999) and 91245 inhabitants (2011). Fifty-six patients with SSc fulfilling the 2013 ACR/EULAR criteria, and in $68 \%$ of them also the 1980 ARA criteria were identified (Female $85.7 \%$, Male:
14.3\%; Caucasian: $96.4 \%$, African 3.6\%; age at diagnosis: $58 ;{ }^{47-80}$ deaths: 13 (8 because of SSc); survival: at 5 years: $89.4 \%(76.2-95.5)$, at 10 years: $84.4 \%$ (69.9-92.3); diffuse SSc: $17.9 \%$, limited SSc: $82.1 \%$; anticentromere: $62.3 \%$, antitopoisomerase I (topo I): $20.8 \%$, anti-RNA polymerase III (RNAP3): $5.4 \%$; antitopo I and RNAP3: 1.9\%; Anti-Th/To: 1.9\%; interstitial lung disease: $23.1 \%$; group 1 pulmonary arterial hypertension $19.6 \%$; renal crisis $5.4 \%$ ). No significant variation of incidence was observed during the period of time evaluated in the study (table 1). Analysis of prevalence revealed a continuous increase of the disease using both the 1980 ARA criteria or 2013 ACR/EULAR criteria $(p<0.001$ for both comparisons; table 2). The prevalence on 2016 was 50.9 per 100000 persons aged $>14$ years, one of the highest ever recorded by SSc epidemiology studies. However, notably, the prevalence in Valcamonica during the first years of the 21 st century was similar to that reported by previous other studies performed in Italy in the same years. ${ }^{1-2}$

Abstract SAT0490 - Table 1. Incidence of SSc in Valcamonica expressed as cases per 100,000 adults aged over 14 -years

\begin{tabular}{|l|c|c|c|c|}
\hline \multicolumn{1}{|c|}{ SEX } & $\begin{array}{c}\text { STUDY } \\
\text { PERIOD }\end{array}$ & $\begin{array}{c}\text { MEAN POPULATION } \\
\text { >14 YEARS }\end{array}$ & NEW CASES & $\begin{array}{c}\text { INCIDENCE } \\
\text { (a 95\%) }\end{array}$ \\
\hline $\begin{array}{l}\text { MALE AND } \\
\text { FEMALE }\end{array}$ & $1999-2004$ & $86,205.5$ & 12 & $\begin{array}{c}2.3 \\
(1.2-4.1)\end{array}$ \\
\cline { 2 - 5 } & $2005-2010$ & $89,448.5$ & 14 & $\begin{array}{c}2.6 \\
(1.4-4.4)\end{array}$ \\
\cline { 2 - 6 } & $2011-2016$ & 90,843 & 16 & $\begin{array}{c}2.9 \\
\end{array}$ \\
\cline { 2 - 6 } & & & & $(1.7-4.8)$ \\
\hline
\end{tabular}

Abstract SAT0490 - Table 2. Estimates of the prevalence of SSc in Valcamonica expressed as cases per 100,000 adults aged over 14-years

\begin{tabular}{|c|l|c|c|c|}
\hline SEX & \multicolumn{1}{|c|}{ YEAR } & $\begin{array}{c}\text { POPULATION } \\
\text { >14 YEARS }\end{array}$ & $\begin{array}{c}\text { IIVING } \\
\text { CASES }\end{array}$ & $\begin{array}{c}\text { PREVALENCE } \\
\text { (a 95\%) }\end{array}$ \\
\hline \multirow{3}{*}{$\begin{array}{c}\text { MALE AND } \\
\text { FEMALE }\end{array}$} & 1999 & 85168 & 14 & $16.4(9-27.6)$ \\
\cline { 2 - 6 } & 2005 & 88011 & 26 & $29.5(19.3-43.3)$ \\
\cline { 2 - 6 } & 2011 & 91245 & 37 & $40.6(28.6-55.9)$ \\
\cline { 2 - 6 } & 2016 & 90441 & 46 & $50.9(37.2-67.8)$ \\
\hline \multirow{5}{*}{ FEMALE } & 1999 & 43755 & 13 & $29.7(15.8-50.8)$ \\
\cline { 2 - 6 } & 2005 & 44751 & 22 & $49.2(30.8-74.4)$ \\
\cline { 2 - 6 } & 2011 & 46149 & 31 & $67.2(45.7-95.3)$ \\
\cline { 2 - 6 } & 2016 & 45868 & 42 & $91.6(66-123.8)$ \\
\hline \multirow{5}{*}{ MALE } & 1999 & 41413 & 1 & $2.4(0-13.5)$ \\
\cline { 2 - 6 } & 2005 & 43260 & 4 & $9.3(2.5-23.7)$ \\
\cline { 2 - 6 } & 2011 & 45096 & 6 & $13.3(4.9-29)$ \\
\cline { 2 - 6 } & 2016 & 44573 & 4 & $9(2.5-23)$ \\
\hline
\end{tabular}

Conclusions: Although the incidence of SSc did not change significantly over time in this area, the disease prevalence constantly increased, with recruitment of new cases exceeding the number of deaths.

\section{REFERENCES}

[1] Airò $P$, et al. Clin Exp Rheumatol 2007;25:878-80.

[2] Lo Monaco A, et al. Clin Exp Rheumatol 2011;29:S10-4.

Disclosure of Interest: None declared

DOI: 10.1136/annrheumdis-2018-eular.4239 